\title{
The role of haem in the regulation of rat liver tryptophan metabolism
}

\author{
Mark SALTER* and Christopher I. POGSON*† \\ *Department of Biochemistry, University of Manchester, Oxford Road, Manchester M13 9PL, U.K., and †Biochemistry \\ Department, Wellcome Research Laboratories, Langley Court, Beckenham, Kent BR3 3BS, U.K.
}

\begin{abstract}
1. At saturating concentrations of tryptophan, the activity of tryptophan 2,3-dioxygenase was the same in isolated liver cells and in extracts with added haematin. 2. Intraperitoneal injection of haematin did not increase tryptophan oxidation in livers subsequently perfused in situ. 3. Preincubation of liver cells with physiological concentrations of tryptophan caused maximal saturation of tryptophan 2,3-dioxygenase with haem in liver cells. 4. In cell-free extracts tryptophan 2,3-dioxygenase exhibited complex kinetics with haem. 5. The results have important implications for the understanding of the role of haem in tryptophan metabolism.
\end{abstract}

\section{INTRODUCTION}

In mammals, more than $90 \%$ of the total tryptophan is degraded in the liver through the 'kynurenine pathway' (Young et al., 1978). Control of this pathway is important because of the relationship between the plasma concentration of tryptophan and the synthesis of 5-hydroxytryptamine in the brain (Curzon, 1979).

Tryptophan 2,3-dioxygenase (EC 1.13.11.11) is a haem-containing enzyme which catalyses the first reaction unique to tryptophan degradation in the liver. It is a cytosolic enzyme whose activity is regulated chronically by tryptophan (Knox, 1951, 1966; Salter et al., 1984) and by various hormones (Knox \& Mehler, 1951; Nakamura et al., 1980; Salter \& Pogson, 1985). Under basal conditions the dioxygenase is largely responsible for the control of the pathway; under conditions where enzyme activity is increased, however, control shifts from the dioxygenase to the systems responsible for transport of the amino acid across the plasma membrane (Salter et al., 1985a, 1986a,b).

Rat liver tryptophan dioxygenase exists as the active holo-enzyme and the haem-free apo-enzyme (Feigelson \& Greengard, 1961; Knox, 1966; Badawy, 1979; Yamamoto et al., 1981; Stowell \& Mørland, 1983; Sadler et al., 1984; Sardana \& Drummond, 1986). The ratio of holo- to apo-enzyme is dependent on the availability of haem (Badawy \& Evans, 1975; Badawy \& Morgan, 1980; Welch \& Badawy, 1980; Badawy et al., 1981) and is influenced by agents that affect the conversion of 5-aminolaevulinate into haem, including tryptophan itself (Badawy et al., 1981; Badawy \& Morgan, 1982).

Although there have been disagreements about the preferred methodology for determining the degree to which the dioxygenase is saturated with haem in liver homogenates (Badawy et al., 1983; Stowell \& Mørland, 1983), it is accepted that a significant proportion of the enzyme in such homogenates is in the unsaturated, or apo-, form. Whether this is the case in whole liver in vivo, however, is not clear.

The purpose of the present work was to determine the degree of haem saturation of tryptophan dioxygenase in whole cells and to relate this to the effects of haem as a possible regulator of dioxygenase activity.
A preliminary description of part of this work has been presented (Salter \& Pogson, 1986).

\section{MATERIALS AND METHODS}

\begin{abstract}
Animals
Male Sprague-Dawley (University of Manchester) and Wistar (Wellcome Research Laboratories) rats $(180-220 \mathrm{~g})$ were used throughout. There was no observable difference in tryptophan metabolism or tryptophan 2,3-dioxygenase between these strains (results not shown).
\end{abstract}

\section{Chemicals}

L-[ring-2-14C]Tryptophan was from CEA, Gif-surYvette, France, through Fluorochem, Glossop, Derbyshire, U.K. [G- $\left.{ }^{3} \mathrm{H}\right]$ Tryptophan was from Amersham International, Amersham, Bucks., U.K. Radiolabelled L-isomers were purified by affinity chromatography (Stewart \& Doherty, 1973) as described by Salter (1985). 2-Allyl-2-isopropylacetamide was a gift from Roche Products, Welwyn Garden City, Herts., U.K. Haem in the form of haematin hydrochloride, L-tryptophan, dexamethasone phosphate and dimethylformamide were from Sigma. The sources of other reagents were as given previously (Smith \& Pogson, 1980; Smith et al., 1980).

\section{Liver perfusion}

All perfusions were started at approx. 13:00 h. Whole livers were perfused in situ through the hepatic vein with $200 \mathrm{ml}$ of buffer (Krebs \& Henseleit, 1932) at $25 \mathrm{ml} / \mathrm{min}$ and $37^{\circ} \mathrm{C}$. This medium was then replaced with $100 \mathrm{ml}$ of the same buffer containing $80 \mu \mathrm{M}-\left[\mathrm{G}-{ }^{3} \mathrm{H}\right]$ tryptophan (sp. radioactivity $3 \mathrm{Ci} / \mathrm{mol}$ ); this medium was recirculated at the same rate through the liver for $30 \mathrm{~min}$. At $5 \mathrm{~min}$ intervals, $0.25 \mathrm{ml}$ samples were taken and mixed with $0.25 \mathrm{ml}$ of a suspension $(50 \mathrm{mg} / \mathrm{ml}$ in water) of Norit GSX, before centrifugation at $12000 \mathrm{~g}$ for $2 \mathrm{~min} ; 0.1 \mathrm{ml}$ of each supernatant was counted for radioactivity of ${ }^{3} \mathrm{H}$-labelled non-aromatic products.

\section{Preparation and incubation of liver cells}

Procedures were as described previously (Smith \& Pogson, 1980; Smith et al., 1980; Salter et al., 1984), 
except that $1.25 \mathrm{~mm}-\mathrm{CaCl}_{2}$ was included in the perfusion medium after addition of collagenase. Glucose $(5 \mathrm{mM})$ was present during cell preparation and incubation. Briefly, flux from tryptophan through tryptophan 2,3-dioxygenase was determined at $37^{\circ} \mathrm{C}$ by measuring the release of ${ }^{14} \mathrm{CO}_{2}$ and ${ }^{14} \mathrm{C}$-labelled non-aromatic products from [ring-2-14 C]tryptophan (Smith et al., 1980). Reactions were terminated by the addition of $0.2 \mathrm{ml}$ of $20 \%(\mathrm{v} / \mathrm{v}) \mathrm{HClO}_{4}$ to incubations.

\section{Enzyme assay}

Tryptophan 2,3-dioxygenase was assayed in whole liver homogenates and liver cell extracts at $37^{\circ} \mathrm{C}$ by a modification of the method of Metzler et al. (1982). Enzyme activity was measured with 2.5 mM-tryptophan either in the absence (holo-enzyme activity) or in the presence (total enzyme activity) of added haematin $(2 \mu \mathrm{M})$. Haematin was present from the beginning of the incubation, and enzyme activity was determined from the linear rate of tryptophan metabolism between 40 and $80 \mathrm{~min}$. The haem saturation of tryptophan 2,3dioxygenase is the percentage of total enzyme activity expressed by the holo-enzyme.

\section{RESULTS AND DISCUSSION}

Table 1 shows the haem saturation of tryptophan 2,3-dioxygenase determined in cell extracts and wholeliver homogenates. These values agree well with values in the literature (Badawy \& Evans, 1975; Badawy, 1981; Yamamoto et al., 1981; Stowell \& Mørland, 1983; Sadler et al., 1984; Sardana \& Drummond, 1986), and demonstrate that, in cell extracts and homogenates, tryptophan 2,3-dioxygenase is far from fully saturated with its cofactor. As expected, addition of further haematin to the incubations did not increase enzyme activity further (results not shown). When cells were incubated with $2.5 \mathrm{~mm}$-tryptophan, the flux through the dioxygenase reaction was $12.75 \pm 0.95 \mathrm{nmol} / \mathrm{h}$ per $\mathrm{mg}$ dry wt.; this rate was not significantly different from that found when enzyme activity was measured in the corresponding cell homogenates supplemented with $2 \mu \mathrm{M}$-haematin $(12.50 \pm 0.60 \mathrm{nmol} / \mathrm{h}$ per $\mathrm{mg}$ dry wt.; both values are means \pm S.E.M. for three separate cell preparations). At lower concentrations of tryptophan, the flux through tryptophan 2,3-dioxygenase in liver cells is limited by substrate supply (Pogson et al., 1984; Salter et al., 1985b, 1986b). When tryptophan is saturating, however, as in the above experiment, the control coefficient (Salter et al., 1986b) of tryptophan transport for tryptophan degradation is less than 0.02 (results not shown). Under these conditions, therefore, transport of the amino acid will not limit its metabolism to any significant extent.

The degree of haem saturation of tryptophan 2,3-dioxygenase was examined in perfused liver. Fig. 1 shows the metabolism of $80 \mu \mathrm{M}-\left[\mathrm{G}-{ }^{3} \mathrm{H}\right]$ tryptophan by perfused liver in situ. Induction of tryptophan 2,3dioxygenase by pretreatment of the animals with

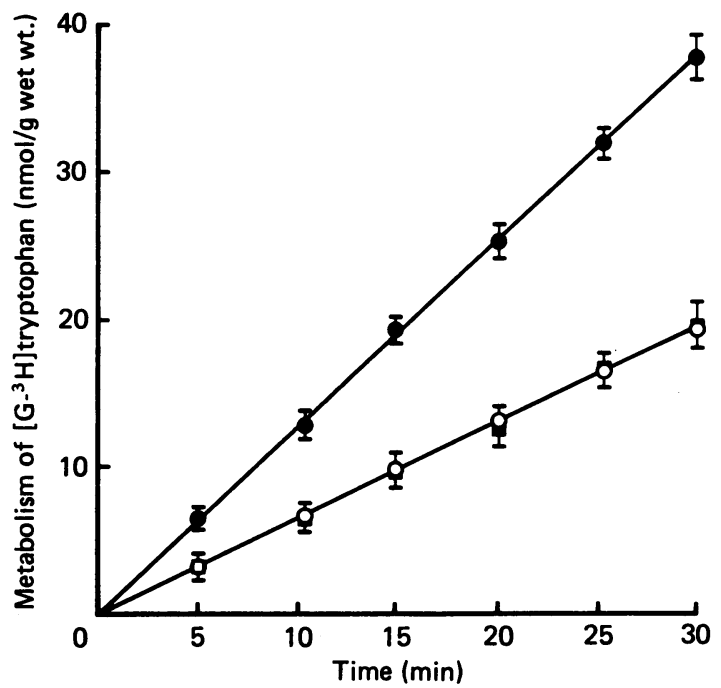

Fig. 1. Effect of haematin and dexamethasone phosphate on the metabolism of [G-3 $\left.{ }^{3} \mathbf{H}\right]$ tryptophan by perfused rat liver

Fed rats were injected intraperitoneally with dexamethasone phosphate $(0 ; 12 \mathrm{mg} / \mathrm{kg}$ in $0.9 \% \mathrm{NaCl}$, $5 \mathrm{~h}$ before perfusion), haematin hydrochloride $(\square ; 6 \mathrm{mg} / \mathrm{kg}$ in dimethylformamide, $2 \mathrm{~h}$ before perfusion) or vehicle ( $O ; 1 \mathrm{ml} / \mathrm{kg}$ in dimethylformamide, $2 \mathrm{~h}$ before perfusion). Livers were pre-perfused with $200 \mathrm{ml}$ of buffer as described in the Materials and methods section, with ( $\square$ ) or without $(\mathrm{O}, 0) 2 \mu \mathrm{M}$-haematin hydrochloride. Perfusion was with $80 \mu \mathrm{M}-\mathrm{L}-\left[\mathrm{G}-{ }^{-} \mathrm{H}\right]$ tryptophan for $30 \mathrm{~min}$. Samples of the perfusate were taken and treated as described in the Materials and methods section. All results are means \pm S.E.M. for three animals.

Table 1. Saturation of tryptophan 2,3-dioxygenase with haem in cell extracts and liver homogenates

Liver cells were prepared from fed rats as described in the Materials and methods section. Samples of cell suspensions ( $2 \mathrm{ml}$; $10 \mathrm{mg}$ dry wt. $/ \mathrm{ml}$ ) were centrifuged $(50 \mathrm{~g}, 2 \mathrm{~min})$; the resulting pellet was extracted by freeze-thawing (three times) with $2 \mathrm{ml}$ of $20 \mathrm{~mm}$-potassium phosphate (pH 7.4)/2.5 mM-tryptophan, with and without $2 \mu \mathrm{M}$-haematin hydrochloride. Whole liver tissue was homogenized with $60 \mathrm{vol}$. (v/w) of the same buffer. Extracts and homogenates were assayed for tryptophan 2,3-dioxygenase activity with and without $2 \mu \mathrm{M}$-haematin as described in the Materials and methods section. Results are means \pm S.E.M. for three animals or separate cell preparations.

\begin{tabular}{lccr}
\hline & Haematin & $\begin{array}{c}\text { Activity of } \\
\text { tryptophan 2,3-dioxygenase } \\
\text { (nmol/h per mg dry wt.) }\end{array}$ & $\begin{array}{r}\text { Saturation } \\
\text { with haem } \\
(\%)\end{array}$ \\
\hline Cell extracts & - & $5.60 \pm 0.30$ & $46 \pm 2$ \\
Homogenates & + & $12.95 \pm 0.60$ & $100 \pm 5$ \\
& - & $5.05 \pm 0.25$ & $48 \pm 2$ \\
& + & $10.50 \pm 0.55$ & $100 \pm 5$
\end{tabular}


dexamethasone phosphate (Salter \& Pogson, 1985) caused a significant $(P<0.001)$ increase in the rate of metabolism of $\left[\mathrm{G}^{3} \mathrm{H}\right]$ tryptophan; haem saturation of tryptophan 2,3-dioxygenase has been shown to be unaffected by administration of glucocorticoids (Badawy \& Evans, 1975). However, pretreatment with haematin, followed by perfusion in the presence of $2 \mu \mathrm{M}$-haematin hydrochloride, yielded rates indistinguishable from those of controls with vehicle alone. The intracellular haem content of liver cells, measured directly by the method of Morrison (1965) (results not shown) or indirectly by the saturation of tryptophan 2,3-dioxygenase (Fig. 2), increased significantly $(P<0.001)$ on incubation of liver cells with $2 \mu \mathrm{M}$-haematin. These data therefore suggest that the concentration of haem remaining in the perfused liver of the control animals was sufficient to maintain total saturation of tryptophan 2,3-dioxygenase.

Badawy has suggested that physiological concentrations of tryptophan increase the conversion of 5aminolaevulinate into haem by activating 5-aminolaevulinate dehydratase (EC 4.2.1.24) and thereby increase the saturation of tryptophan 2,3-dioxygenase with haem (Badawy et al., 1981; Badawy \& Morgan, 1982). Fig. 2 shows the effect of tryptophan on the haem saturation of tryptophan 2,3-dioxygenase in isolated liver cells. It is clear that the enzyme is initially unsaturated with cofactor; however, addition of concentrations of tryptophan that are in the physiological range or below (Madras et al., 1973; Curzon \& Knott,

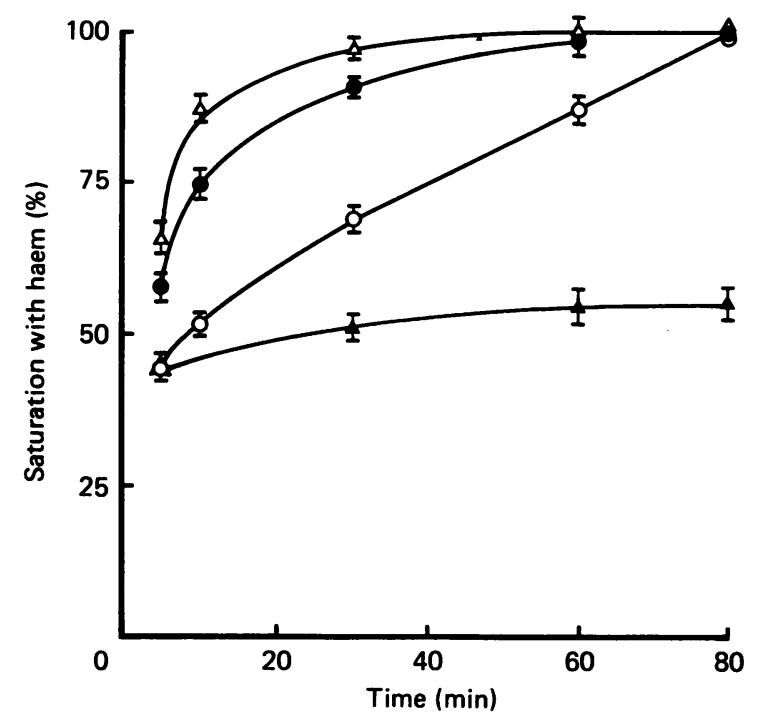

Fig. 2. Effect of tryptophan on the haem saturation of tryptophan 2,3-dioxygenase in isolated liver cells

Liver cells were prepared from fed rats as described in the Materials and methods section. Samples of cells $(2 \mathrm{ml}$; $10 \mathrm{mg}$ dry $\mathrm{wt} . / \mathrm{ml}$ ) were preincubated with and without $2 \mu \mathrm{M}$-haematin hydrochloride for $\mathbf{3 0} \mathrm{min}$. Tryptophan $(\Delta$, $0 \mu \mathrm{M} ; \bigcirc, 5 \mu \mathrm{M} ; O, 50 \mu \mathrm{M} ; \Delta, 150 \mu \mathrm{M})$ was then added and incubations were continued for various periods $(0,5,25$, 55 and $75 \mathrm{~min}$ ) before addition of $\mathrm{L}-[$ ring-2-14 C]tryptophan (final sp. radioactivity $3 \mathrm{Ci} / \mathrm{mol}$ ). Incubations were terminated 5 min later and were treated as described in the Materials and methods section. Results are means \pm S.E.M. from three separate cell preparations.
1974; Bloxam et al., 1975; Badawy et al., 1984) resulted in the complete saturation of tryptophan 2,3-dioxygenase with haem.

When liver cells were prepared in the presence of $5 \mu \mathrm{M}$-tryptophan, and were then incubated with $5 \mu \mathrm{M}$ tryptophan for $30 \mathrm{~min}$, the flux through tryptophan 2,3-dioxygenase over this period was similar both with and without exogenous $2 \mu \mathrm{M}$-haematin, indicating that the enzyme was fully saturated with its cofactor in the freshly prepared cells (cf. Fig. 2). It is therefore likely that the partial haem saturation of tryptophan 2,3dioxygenase shown in Fig. 2 was due to a decrease in intracellular haem as a result of preparation of the liver cells in the absence of tryptophan. In vivo, the presence of normal plasma concentrations of free tryptophan (5-20 $\mu$ M) (Madras et al., 1973; Curzon \& Knott, 1974; Bloxam et al., 1975; Badawy et al., 1984) will therefore probably be sufficient to maintain tryptophan 2,3dioxygenase in a fully haem-saturated state. The effect of preincubation of tryptophan with liver cells on the haem-saturation of tryptophan 2,3-dioxygenase, assayed in cell-free extracts, is shown in Table 2 . Tryptophan was clearly much less effective as a promoter of haem saturation than in the experiments described above (cf. Fig. 2). This is attributable to the dilution of the intracellular haem pool during extraction. However, incubation of liver cells with $100 \mu \mathrm{M}$-tryptophan increased haem sufficiently to saturate the enzyme totally, even after dilution on homogenization (cf. Badawy et al., 1981). It therefore appears that assay of the extracted enzyme with and without haematin is inappropriate as a way of determining the saturation of tryptophan 2,3-dioxygenase with its cofactor in vivo. Incubation of liver cells with $100 \mu \mathrm{M}$-tryptophan (Table 2 ) not only promoted total haem saturation of tryptophan 2,3-dioxygenase but also increased its total activity. This is consistent with claims that in vivo tryptophan increases tryptophan 2,3dioxygenase protein by decreasing its rate of degradation (Schimke et al., 1965).

Fig. 3 shows the relationship between haem concentration and dioxygenase activity in cell-free extracts. The enzyme exhibited complex kinetics with haem; this is consistent with the hypothesis that tryptophan 2,3dioxygenase possesses at least two distinct haem-binding sites. Many groups have reported haem saturations of approx. $50 \%$ in whole liver homogenates (Yamamoto et al., 1981, 1982; Badawy \& Morgan, 1982, and references therein; Stowell \& Mørland, 1983; Sadler et al., 1984; Sardana \& Drummond, 1986). It is probable that, on homogenization and consequent dilution, haem will dissociate from the low-affinity site(s); the high-affinity site(s) will, however, retain most of the haem until very low haem concentrations are reached. Haem from the high-affinity site(s) will only dissociate extensively under conditions of severe haem depletion, e.g. after treatment with a porphyrogen such as 2-allyl-2-isopropylacetamide and subsequent dilution of the free haem pool by homogenization (Badawy \& Morgan, 1980).

It has been reported that tryptophan 2,3-dioxygenase in some species such as the guinea pig exists exclusively as holo-enzyme when assayed in liver homogenates (Hvitfelt \& Santti, 1972; Badawy \& Evans, 1974). One might speculate that the guinea-pig enzyme possesses only high-affinity haem-binding sites and that haem concentrations present in liver homogenates are therefore sufficient to maintain saturation of the enzyme. 
Table 2. Effect of incubation of liver cells with tryptophan on the haem saturation of tryptophan 2,3-dioxygenase in cell extracts

Liver cells were prepared from fed rats as described in the Materials and methods section. Samples $(2 \mathrm{ml} ; 10 \mathrm{mg} \mathrm{dry} \mathrm{wt./ml)}$ were incubated with and without tryptophan for $90 \mathrm{~min}$ before centrifugation at $50 \mathrm{~g}$ for 2 min. Pellets were extracted and assayed for dioxygenase activity, with and without haematin, as described in Table 1 . Results are means \pm S.E.M. for three liver cell preparations.

\begin{tabular}{cccr}
\hline $\begin{array}{c}\text { Tryptophan } \\
(\mu \mathrm{M})\end{array}$ & $\begin{array}{c}\text { Haematin } \\
(2 \mu \mathrm{M})\end{array}$ & $\begin{array}{c}\text { Activity of } \\
\text { tryptophan 2,3-dioxygenase } \\
(\text { nmol/h per mg dry wt.) }\end{array}$ & $\begin{array}{c}\text { Saturation } \\
\text { with haem } \\
(\%)\end{array}$ \\
\hline \multirow{2}{*}{0} & - & $4.30 \pm 0.25$ & $35 \pm 2$ \\
& + & $12.30 \pm 0.75$ & $100 \pm 6$ \\
5 & - & $5.65 \pm 0.25$ & $46 \pm 2$ \\
25 & + & $12.35 \pm 0.65$ & $100 \pm 5$ \\
100 & + & $10.20 \pm 0.45$ & $100 \pm 3$ \\
& - & $13.65 \pm 0.40$ & $104 \pm 7$ \\
& + & $21.60 \pm 1.50$ & $100 \pm 6$
\end{tabular}

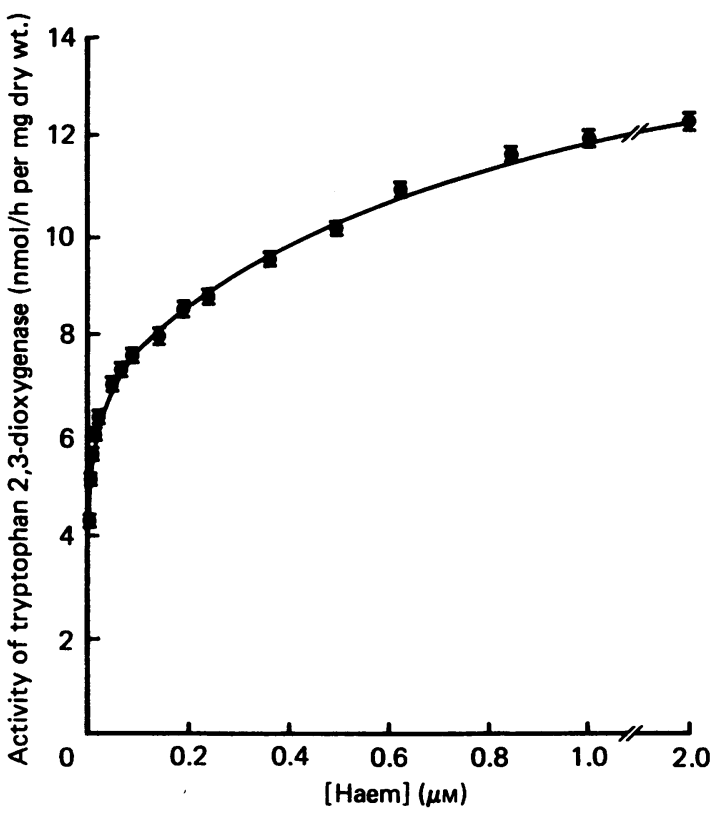

Fig. 3. Effect of haematin hydrochloride on tryptophan 2,3dioxygenase activity in liver cell extracts

Liver cells were prepared from fed rats as described in the Materials and methods section, and $2 \mathrm{ml}$ samples $(10 \mathrm{mg}$ dry wt./ml) were incubated in the presence of $150 \mu \mathrm{M}$ 2-allyl-2-isopropylacetamide for $60 \mathrm{~min}$ and then centrifuged $(50 \mathrm{~g}, 2 \mathrm{~min})$, washed in $10 \mathrm{ml}$ of the above medium in the absence of 2-allyl-2-isopropylacetamide, centrifuged $(50 \mathrm{~g}, 2 \mathrm{~min})$ and the supernatant discarded. The cell pellet was extracted and assayed for tryptophan 2,3-dioxygenase activity as described in Table 1. 2-Allyl-2-isopropylacetamide was added to cell incubations to decrease the haem concentration and thus cause more apo-tryptophan 2,3-dioxygenase to be present for titration with exogenous haematin (Badawy \& Morgan, 1980). Results are means \pm S.D. from one liver cell preparation.

\section{General discussion}

The major conclusion to be drawn from these observations is that tryptophan 2,3-dioxygenase is fully saturated with its cofactor in vivo. It appears that even large decreases in the concentration of intracellular free haem may be ineffective in depleting flux through the kynurenine pathway; increases in haem will certainly be ineffective. Fluctuation in the liver tryptophan concentration (and thus haem concentration) is therefore unlikely to precipitate changes in the rate of tryptophan metabolism through changes in the saturation of tryptophan 2,3-dioxygenase with haem. Measurements of the saturation of tryptophan 2,3-dioxygenase with haem in liver homogenates clearly do not reflect the haem status of tryptophan 2,3-dioxygenase in vivo. However, as a qualitative indication of the free haem available to tryptophan 2,3-dioxygenase and 5-aminolaevulinate synthase (Badawy \& Morgan, 1982), such measurements may have some validity.

The initial part of this work was supported by the Medical Research Council.

\section{REFERENCES}

Babawy, A. A.-B. (1979) Biochem. Soc. Trans. 7, 575-584

Badawy, A. A.-B. (1981) J. Pharmacol. Methods 6, 77-85

Badawy, A. A.-B. \& Evans, M. (1974) Biochem. J. 138, 445-451

Badawy, A. A.-B. \& Evans, M. (1975) Biochem. J. 150, 511-520

Badawy, A. A.-B. \& Morgan, C. J. (1980) Biochem. J. 186, 763-772

Badawy, A. A.-B. \& Morgan, C. J. (1982) Biochem. J. 206, 451-460

Badawy, A. A.-B., Welch, A. N. \& Morgan, C. J. (1981) Biochem. J. 198, 309-314

Badawy, A. A.-B., Morgan, C. J. \& Davis, N. R. (1983) Biochem. J. 215, 709-710

Badawy, A. A.-B., Morgan, C. J., Davis, N. R. \& Dacey, A. (1984) Biochem. J. 217, 863-864

Bloxam, D. L., Warren, W. H. \& White, P. J. (1975) Life Sci. 15, 1443-1455

Curzon, G. (1979) J. Neural Transm. Suppl. 15, 81-92

Curzon, G. \& Knott, P. J. (1974) Br. J. Pharmacol. 50, 197-204

Feigelson, P. \& Greengard, O. (1961) J. Biol. Chem. 236, 153-157

Hvitfelt, J. \& Santti, R. S. (1972) Biochim. Biophys. Acta 258, 358-365

Knox, W. E. (1951) Br. J. Exp. Pathol. 32, 462-469

Knox, W. E. (1966) Adv. Enzyme Regul. 4, 287-297

Knox, W. E. \& Mehler, A. H. (1951) Science 113, 237-238

Krebs, H. A. \& Henseleit, K. (1932) Hoppe-Seyler's Z. Physiol. Chem. 210, 33-66 
Madras, B. K., Cohen, E. L., Fernstrom, J. D., Larin, F., Munro, H. N. \& Wurtman, R. J. (1973) Nature (London) 244, 34-35

Metzler, H., Gebhardt, R., Oberauch, W. \& Mecke, D. (1982) Anal. Biochem. 121, 10-16

Morrison, G. R. (1965) Anal. Chem. 37, 1124-1126

Nakamura, T., Shinno, H. \& Ichihara, A. (1980) J. Biol. Chem. 255, 7533-7535

Pogson, C. I., Carpenter, W. R., Cook, J. S., Fisher, M. J., Lomax, M. A., Salter, M. \& Stanley, J. C. (1984) Proc. Nutr. Soc. 43, 119-132

Sadler, E. M., Weiner, M. \& Buterbaugh, G. G. (1984) Life Sci. 34, 1365-1370

Salter, M. (1985) Ph.D. Thesis, University of Manchester

Salter, M. \& Pogson, C. I. (1985) Biochem. J. 229, 499-504

Salter, M. \& Pogson, C. I. (1986) Biochem. Soc. Trans. 14, 10631064

Salter, M., Stanley, J. C., Fisher, M. J. \& Pogson, C. I. (1984) Biochem. J. 221, 431-438

Salter, M., Knowles, R. G. \& Pogson, C. I. (1985a) Biochem. Soc. Trans. 13, 693-694

Salter, M., Bender, D. A. \& Pogson, C. I. (1985b) Biochem. J. 225, 277-281

Received 12 June 1986/26 August 1986; accepted 19 September 1986
Salter, M., Knowles, R. G. \& Pogson, C. I. (1986a) Biochem. J. 233, 499-506

Salter, M., Knowles, R. G. \& Pogson, C. I. (1986b) Biochem. J. 234, 635-647

Sardana, M. K. \& Drummond, G. S. (1986) Biochem. Pharmacol. 35, 473-478

Schimke, R. T., Sweeney, E. W. \& Berlin, C. M. (1965) J. Biol. Chem. 240, 322-331

Smith, S. A. \& Pogson, C. I. (1980) Biochem. J. 186, 977986

Smith, S. A., Carr, F. P. A. \& Pogson, C. I. (1980) Biochem. J. 192, 673-686

Stewart, K. K. \& Doherty, R. F. (1973) Proc. Natl. Acad. Sci. U.S.A. 70, 2850-2852

Stowell, L. \& Mørland, J. (1983) Biochem. J. 209, 831-836

Welch, A. N. \& Badawy, A. A.-B. (1980) Biochem. J. 192, 403-410

Yamamoto, M., Hayashi, N. \& Kikuchi, G. (1981) Arch. Biochem. Biophys. 209, 451-459

Yamamoto, M., Hayashi, N. \& Kikuchi, G. (1982) Biochem. Int. 5, 747-754

Young, S. N., St. Arnaud-McKenzie, D. \& Sourkes, T. L. (1978) Biochem. Pharmacol. 267, 763-767 